\title{
Internationalizing Higher Education: The Effect of Country-of-Origin on the Evaluation of Service Quality
}

\author{
Jessica Sze Yin $\mathrm{Ho}^{1}$ and Yeoh Sok Foon ${ }^{2}$ \\ ${ }^{1}$ Sunway University Business School, Selangor, Malaysia \\ ${ }^{2}$ Faculty of Management and IT, UCSI University, Kuala Lumpur, Malaysia
}

\begin{abstract}
As the higher education industry in Asia is prospering, attracting students internationally is becoming more competitive for countries in the region, particularly in Malaysia. The establishment of foreign universities in Malaysia has contributed to healthy competition in the higher education sector as these foreign universities provide potential students with more choices for degrees according to the university country-of-origin (COO). Inevitably, service quality offered by a university is among the most important determinants on a student's behavioral intention. Hence, this paper aims to explore the relationship between a university country-of-origin, university service quality and its effect on university students' behavioral intention (word-of-mouth and eventually intention for further study). Data is analyzed using an independent sample t-test and bivariate analysis. Contrary to previous research, results show that there are no significant differences between service quality, word-of-mouth and intention for further study and the university COO. Justification and implications of the study are discussed.
\end{abstract}

Keywords: Country-of-origin, perceived service quality, behavioral intention, higher education.

\section{Introduction}

The higher education sector in Malaysia has been flourishing over the past twenty years. Besides concentrating efforts to provide more higher education opportunities to domestic students, the educational establishment in the country has also been strategizing to attract more international students by aiming to become the regional education hub for the Asia Pacific region. In reference to the statistics reported by the Ministry of Higher Education in the year 2008, Malaysia currently attracts international students from various countries such as China, Indonesia, Nigeria,
Bangladesh and various Middle Eastern countries (MOHE, 2010). Attracting both domestic and international students is a constant challenge. Even though the number of students recruited over recent years has been increasing, there are signs of mounting competition (Ahmad Faiz, 2007).

Various perceived service quality models have been discussed in the literature, the application of a perceived service quality model in Malaysia (a developing country that is rapidly growing its education sector) calls for a more thorough model with different variables confined under various culture practices. Controversies between the

Copyright (C) 2012 Jessica Sze Yin Ho and Yeoh Sok Foon. This is an open access article distributed under the Creative Commons Attribution License unported 3.0, which permits unrestricted use, distribution, and reproduction in any medium, provided that original work is properly cited. Contact author: Jessica Sze Yin HO E-mail: jessicah@sunway.edu.my 
available models and instruments, for perceived service quality in higher education, be it SERVPERF by Cronin and Taylor (1992) or HEdPERF by Firdaus (2006) urge for thorough studies to be conducted in this area. Hence, Brocado (2009) concluded it is important for future studies to compare the measurements across different samples to test the consistency of the available instruments. In addition to that, service quality also has an effect on student satisfaction and behavioral responses such as a student's loyalty and intention to recommend (Joseph et al., 2005). Thus, measuring service quality perception should not merely be concentrated at the level of quality, but should also measure its implication on the potential behavioral responses among consumers, such as satisfaction and intention to recommend.

Service quality can contribute towards having a lasting impact on the institution and on the consumers they serve, in other words, the students (LeBlanc and Nguyen, 1997). Quality services also act as a pull factor to attract more international students when the graduates return to their home country and spread positive information about the institution to potential students by word-ofmouth (Allen and Davis, 1991). To stay competitive in the arena of higher education, studies about the retention of domestic student, to stay in the country for further education, as well as the attraction of international students, to come into the country, are indispensable.

Country-of-origin (COO) studies are mostly done in the product sector, and the unique characteristics of the service sector demands a separate set of evaluation criteria for $\mathrm{COO}$ studies compared to the product sector. Unfortunately, research related to COO in the service sector is still rather elementary. A thorough literature review by Javalgi et al., (2001) that takes into consideration related journals for a period of 20 years only managed to identify 19 studies that relate COO studies in the service industry. Similarly, Al-Sulaiti and Baker (1998) only managed to identify seven service related studies out of the 99 COO studies reviewed. The rapid growth of service economies, coupled with a lack of studies focusing on international services calls for continuous research in the said area (Javalgi et al., 2001).

Given the issues discussed in the earlier sections, this study aims to address the key question: What is the relationship between country-of-origin (COO) and perceived service quality for the aspect of higher education in Malaysia? How does this relationship affect students' behavioral intentions (word-of-mouth and eventually intention to recommend the institution to others)? This paper will answer these key questions by proposing a framework that would provide a better linkage between service country-of-origin (COO), perceived service quality and its impact on students' behavioral intentions.

\section{Literature Review}

\section{Service Quality in Education}

Quality management is imperative as a measurement of performance standard for both products and services. From a customers' viewpoint, service quality is the consumer's conclusion about an entity overall excellence (Zeithaml and Bitner, 2003). The higher education industry relies essentially on quality management to stay competitive (Yeo, 2009). Every stakeholder in higher education (e.g. students and government) has their own view of quality depending on their particular needs (Voss et al., 2007). O'Niel and Palmer (2004) define service quality in higher education as the discrepancy between students expectation versus perception of delivery. Yeo (2009) has linked service quality and higher education using three interrelated perspectives to define the scope of quality: "First is the perspective of conformance to requirements based on customer expectations (Crosby, 1979); second is the perspective of fitness for use as determined 
by the customer (Juran, 1945); and third is the perspective of willingness to pay based on what the customer can get out rather than what the supplier puts in (Drucker, 1985)". Although there are various definitions of service quality from the educational perspective, the most importantly facets of these definitions is the common agreement, in most of the literature, that the consideration of students in higher educational institutions are the "primary customers" that provides a valuable source of information for a higher educational institution. Hence, understanding student-perceived quality is an important priority for universities and their management (Voss et al., 2007; Brocado, 2009).

Researchers in the past have introduced various means of measuring service quality in higher education. The gap-based analysis represented by SERVQUAL is a commonly used tool to measure service quality in higher education (Brocado, 2009). Nevertheless, Cronin and Taylor (1994) claimed that SERVPERF explains more of the variance in the overall measure of service quality compared to SERVQUAL. Owing to SERVQUAL's popularity, SERVPERF application, in the context of higher education, is less when compared to SERVQUAL (Brocado, 2009). Recently, a new scale HEdPERF, based on SERVPERF, has been created especially for the higher education sector (Firdaus, 2006). HedPERF takes into consideration not only the academic components, but also aspects of the total service environment as experienced by students. According to (Brocado, 2009), SERVPERF and HEdPERF present the best measurement against SERVQUAL, weightedSERVQUAL and Weighted-SERVPERF. Brocado (2009), however, could not identify which one was the best between SERVPERF and HEdPERF. According to Palmer (2008), each of the approaches (performance-only measures, disconfirmation models and importance-performance approaches) to understanding and measuring service quality are not mutually exclusive, and organizations use of quality measurement methodology often combines elements of more than one approach. Since this study places an emphasis on the investigation of the relationship between service quality and elements such as $\mathrm{COO}$ and brand effect rather of gap-analysis between expected and perceived service, this study adopts the performance-only measure approach to measuring service quality.

Over the years, researchers have derived multiple variables to measure the element of service quality in the educational sector. SERVPERF shares the same dimensions as SERVQUAL, based solely on the perception component. Yeo (2009) summarized the SERVQUAL dimensions, from Zeithaml et al., (1990), from the educational perspective in the following way:

1) Tangibility: Physical facilities, equipment and appearance of university staff.

2) Reliability: The ability to perform the promised service dependably and accurately.

3) Responsiveness: The willingness to help students and provide prompt advice and service.

4) Assurance: The ability of university staff to demonstrate competence, courtesy, credibility and security.

5) Empathy: The ability to care and provide individual attention to students.

On the other hand, HEdPERF, introduced by Firdaus (2006), that caters specifically for the higher education industry is made up of the following five dimensions (Brocado, 2009):

1) Non-academic Aspects: Items that are essential to enable students to fulfill their study obligations and relate to duties carried out by non-academic staff. 
2) Academic Aspects: Responsibilities of academics.

3) Reputation: Importance of higher learning institutions in projecting a professional image.

4) Access: Includes issues as approachability, ease of contact, availability and convenience.

5) Program Issues: Importance of offering wide ranging and reputable academic programs/specializations with flexible structures and health services.

In addition to the variables proposed in SERVQUAL, SERVPERF and HEdPERF, similar as well as new variables related to service quality evaluation in the educational sector have also been evaluated by past scholars. Some of these variables are summarized by Yan et al., (2008) (Table 1).

Table 1: Additional Variables for Service Quality Evaluation in the Educational Sector

\begin{tabular}{|l|l|}
\hline Variables & Literature \\
\hline $\begin{array}{l}\text { Academic } \\
\text { teaching/academic staff } \\
\text { quality }\end{array}$ & $\begin{array}{l}\text { Athiyaman, 1997; Joseph and Joseph, 1997; Athiyaman, 2000; } \\
\text { Joseph and Joseph, 2000; Oldfield and Baron, 2000; Nguyen and } \\
\text { LeBlanc, 2001; Mazzarol and Soutal, 2002; Joseph, et al., 2005. }\end{array}$ \\
\hline $\begin{array}{l}\text { Physical aspects of } \\
\text { education environment }\end{array}$ & $\begin{array}{l}\text { Joseph and Joseph, 1997; Athiyaman, 2000; Joseph and Joseph, } \\
\text { 2000; Oldfield and Baron, 2000; Mazzarol and Soutal, 2002; } \\
\text { Nguyen and LeBlanc, 2001; Joseph, et al., 2005. }\end{array}$ \\
\hline Curriculum/Program & $\begin{array}{l}\text { Joseph and Joseph, 1997; Joseph and Joseph, 2000; Mazzarol and } \\
\text { Soutal, 2002; Joseph, et al., 2005. }\end{array}$ \\
\hline Administrative staff support & $\begin{array}{l}\text { Joseph and Joseph, 1997; Joseph and Joseph, 2000; Nguyen and } \\
\text { LeBlanc, 2001; Oldfield and Baron, 2000. }\end{array}$ \\
\hline Reputation of the institution & $\begin{array}{l}\text { Joseph and Joseph, 1997; Joseph and Joseph, 2000; Nguyen and } \\
\text { LeBlanc, 2001; Mazzarol and Soutal, 2002. }\end{array}$ \\
\hline Learning outcomes & $\begin{array}{l}\text { Athiyaman, 1997; Joseph and Joseph, 1997; Joseph and Joseph, } \\
\text { 2000. }\end{array}$ \\
\hline
\end{tabular}

\section{Country-of-Origin and its Relationship with Service Quality}

Most research related to the application of COO has focused on products since the 1960s, but its application into the services field is relatively little (Javalgi et al., 2001; Berentzena et al., 2008). It is not surprising that most previous definitions of COO were derived from it being applied to tangible products. Al-Sulaiti and Baker (1998) has cited the definition from various sources as: "...country where corporate headquarters of the company marketing the product or brand is located", "...the country of manufacture or assembly" and "... used the term "made in - -". Adapting from early scholars, some authors prefer to use a simpler way of defining country-of-origin. For example, as Chattalas et al. (2008) cited, "following Zhang (1996, p. 51), we define COO simply as "information pertaining to where a product is made,"..."Made in"." Consumers can be affected by the extrinsic cue of the $\mathrm{COO}$ of a product (Bilkey and Nes, 1982). Studies involving the measurement of the magnitude of $\mathrm{COO}$ effects on product evaluation, such as perceived quality, attitude and purchase intention are also available (Verlegh and Steenkamp, 1999). A study has related $\mathrm{COO}$ and its influence on consumers' perception on quality to commonly available in the multidimensionality of the COO effect (Chryssochoidis, et al., 2007).

Even though the application of $\mathrm{COO}$ in the tangible product field is huge, the rapid growth of the global services markets also demands for more studies related to $\mathrm{COO}$ to 
be done in the service area. Al-Sulaiti and Baker (1998) and Javalgi et al. (2001) for instance have identified only a small number of studies related to $\mathrm{COO}$ in the service industry. COO studies were clustered around the areas of core services (e.g. medical care or travel services), supplementary services provided to enhance product value (e.g. warranty or guarantee), as well as crossnational service comparisons (Javalgi, et al., 2001). Like the tangible product category, few COO studies in the service category also evaluate the effect of $\mathrm{COO}$ on consumer quality perceptions. Pecotich, et al.'s (1996) study in the airlines industry found that service quality perception is indeed different in reference to COO. Stanton and Veale (2009) proposed that the "... more positive image of the country where the service is provided will lead to a higher level of perceived service quality". Due to limited research of $\mathrm{COO}$ from the service aspect, few studies combine $\mathrm{COO}$ and service quality in the higher education sector. Webb and Po (2000) found that there is a significant COO effect for expectation of service quality in the higher education setting in Western Australia. Similar findings were supported by Li and Liu (2009) as they proved that country image does influence Chinese students' perceptions of higher education of a foreign country.

\section{Service Quality and its Relationship with Behavioral Intention}

Studies related to service quality in various service sectors often link service quality with overall satisfaction as well as behavioral intentions (Boulding, et al., 1993; Zeithaml, et al., 1996), such as purchase intention (e.g. Pérez, et al, 2007; Yap and Kew, 2007; Bai, et al., 2008) as well as 'word-of-mouth' communication (e.g. Athiyaman, 2000; Voss, et al., 2007). Brocado (2009) stresses that in the higher educational sector, intention of future visits and intention to recommend the university to a friend were the preferred outcomes of the service quality and overall satisfaction variables. Level of service quality delivered, whether satisfactory or not, is strongly related to the spread of positive or negative word-of-mouth. Athanassopoulos et al. (2001) citing Zeithaml et al. (1996) said, "service quality is positively associated with communicational behavioral intentions (e.g. intention to recommend the service producer and/or complaining behavior)." A potential student can learn a lot about a particular higher education institution and form expectations about the quality of service to be received, from people who have attended or are attending the institution (Athiyaman, 2000). This is supported by Mazzarol \& Soutar (2002) as they also agree that the most significant force attracting international students involves personal recommendations from those who are studying or have graduated from that particular institution or country. Voss et al. (2007) believe that satisfied students are often encouraged to return to the university to take further courses and at the same time be able to attract new students through word-of-mouth.

This study focuses on evaluating the association between country-of-origin (COO) of the university and perceived service quality and its implications on behavioral intentions, from the aspect of higher education in Malaysia. In order to answer the research objective presented, this study applies a performance-only measures approach to measure perceived service quality. The proposed conceptual framework of this study as derived from the literature is presented in Figure 1. 


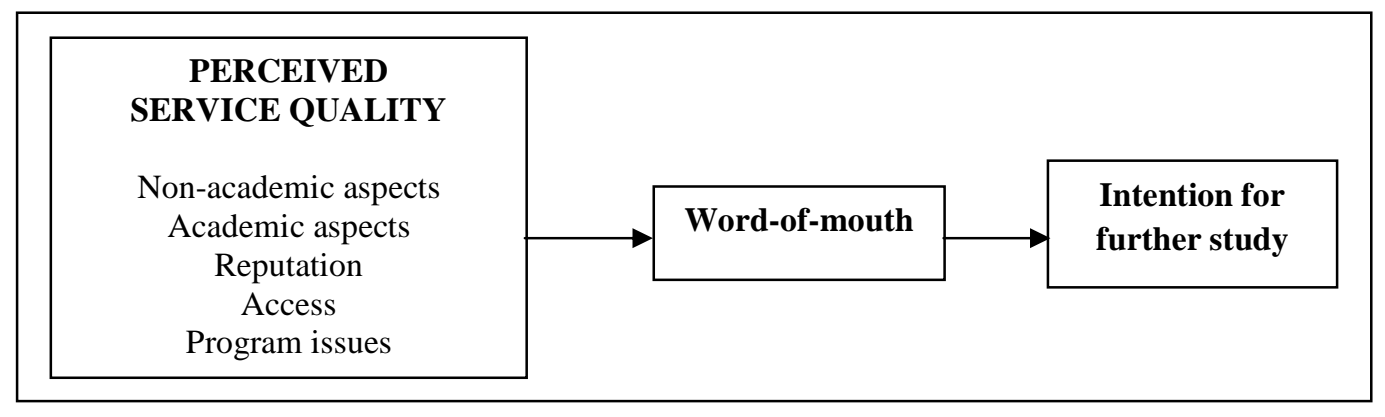

Figure 1: Research Framework of the Study

\section{Research Methodology}

Data collection was carried out at two private universities located in Malaysia. One is an established local institution and the other one is a foreign university branch campus. Both institutions were ranked 'Tier 5 - Excellent' under the 2009 Rating Systems for Malaysian Higher Education Institutions (SETARA'09). Only international students participated in this study. Service quality was adapted from Firdaus (2006) equal to 42 items by a five-point ordinal scale from strongly disagree (one point) at one end to strongly agree at the other end ( 5 points). It consists of five dimensions: non-academic aspects (12 items), academic aspects (9 items), reputation (10 items), access (8 items) and program issues (2 items). Items for word-of-mouth (6 items) were adapted from Bove et al. (2003), and intention for further studies (5 items) in their current institution was adapted from Meng et al. (2011). Both of the dimensions for word-of- mouth and eventually intention for further studies were measured on a five-point ordinal scale. In this pilot study, a total of 78 complete questionnaires were analyzed using Statistical Package for Social Science (SPSS) version 19.0. Prior to performing analyses of reliability and bivariate analyses, summation scores were calculated for each variable.

\section{Results and Discussion}

Generally, respondents are aged $15-20$ years $(S D=4.46)$. In terms of gender, more than half $(67.9 \%)$ of the respondents are males. Almost all respondents (96.2\%) are pursuing their studies at the undergraduate level. At their current university, the majority of the participants are in the $2^{\text {nd }}$ year $(43.6 \%)$ or $1^{\text {st }}$ year $(39.7 \%)$ of their studies. Respondents are almost equally represented with $46.2 \%$ of them coming from a local university, the remaining $53.8 \%$ coming from a foreign university.

Table 2: Profile of Respondents

\begin{tabular}{|l|l|l|l|l|l|l|l|l|l|}
\hline Characteristic & $\mathbf{N}$ & $\mathbf{\%}$ & $\mathbf{M}$ & SD & Characteristic & $\mathbf{N}$ & $\mathbf{\%}$ & $\mathbf{M}$ & SD \\
\hline Gender & & & & & Year of study & 7 & 9.0 & & \\
\hline Male & 53 & 67.9 & & & 1 & 31 & 39.7 & & \\
\hline Female & 25 & 32.1 & & & 2 & 34 & 43.6 & & \\
\hline Age & & & 20.15 & 4.46 & 3 & 6 & 7.7 & & \\
\hline Level of study & & & & & 4 and above & 6 & 7.7 & & \\
\hline Pre-university & 3 & 3.8 & & & $\begin{array}{l}\text { University } \\
\text { Coo }\end{array}$ & & & & \\
\hline Degree & 75 & 96.2 & & & Local & 36 & 46.2 & & \\
\hline & & & & & Foreign & 42 & 53.8 & & \\
\hline
\end{tabular}


Table 3 presents the results of descriptive, reliability and Independent Sample t-test of COO from the institutions for selected variables. Reliability of the scale is in the ranging of 0.59 to 0.92 . According to George and Mallery (2003), an alpha value of 0.7 and above is acceptable and good. On the other hand, an alpha value of 0.5 to 0.6 is considered poor but this can probably occur in a highly homogenous sample (Bernardi, 1994). Overall, results suggest that service qualities delivered by the institutions are considered equally good. Generally, the students agreed that academic aspects are good followed by reputation and program issues. However, there are no significant differences $(t<1.96)$ among service quality, word-of-mouth and intention for further study in that institution with COO of the institution. This is contradictory to Webb and Po (2000) as well as Li and Liu (2009), whose findings suggest the effect of $\mathrm{COO}$ on institutions is in the expectations of service quality. This contradictory result can be attributed to the fact that the two universities selected in this study were amongst the top private universities in the country, which denotes an almost equal level of service quality perception.

Table 3: Results of Descriptive, Reliability and Independent Sample T-Test of COO from the Institutions for Selected Variables

\begin{tabular}{|l|l|l|l|l|l|l|r|}
\hline & Range & $\boldsymbol{M}$ & $\boldsymbol{S D}$ & $\boldsymbol{\alpha}$ & $\begin{array}{l}\text { No. of } \\
\text { items }\end{array}$ & Variance & $\boldsymbol{t}$ \\
\hline Non academic aspects & $12-60$ & 36.74 & 9.15 & 0.92 & 12 & 83.80 & 1.42 \\
\hline Academic aspects & $9-45$ & 32.50 & 4.83 & 0.82 & 9 & 23.31 & -1.37 \\
\hline Reputation & $10-50$ & 34.3 & 5.34 & 0.77 & 10 & 28.55 & 0.14 \\
\hline Access & $8-40$ & 25.68 & 6.24 & 0.60 & 8 & 39.70 & -0.02 \\
\hline Program issues & $2-10$ & 6.85 & 1.59 & 0.59 & 2 & 2.24 & -0.22 \\
\hline Word-of-mouth further & $6-30$ & 19.80 & 5.12 & 0.91 & 6 & 26.20 & -0.65 \\
\hline $\begin{array}{l}\text { Intention for } \\
\text { study }\end{array}$ & 14.34 & 4.67 & 0.89 & 5 & 27.78 & 0.35 \\
\hline
\end{tabular}

Results of correlation analysis (Table 4) show that there are significant relationships between non- academic aspects $(r=0.39, p<$ $0.01)$, reputation $(r=0.31, p<0.01)$, access $(r=0.26, p<0.01)$, program issues $(r=0.36$, $p<0.01)$ and word-of-mouth $(r=0.50, p<$ 0.01 ) with intention for further study except academic aspects $(r=0.19, p>0.05)$. In other words, word-of-mouth accounts for $25.0 \%$ of the variability in intention for further study followed by non-academic aspects (15.0\%) and program issues
$(12.0 \%)$. It is worth noting that although the university students generally perceived good academic aspects of service quality, it is not statically related to their intention for further study. This is contrary to a previous study by Voss et al. (2007) in which the researchers quoted the relationship between positive perception of service quality and positive behavioral intention. This result is justifiable as the academic staff evaluated in this study do not remain constant at all levels of study. 
Table 4: Results of Correlation Matrix between Service Quality, Word or Mouth and Intention for Further Study in that Institution

\begin{tabular}{|c|c|c|c|c|c|c|c|}
\hline & 1 & 2 & 3 & 4 & 5 & 6 & 7 \\
\hline Non-academic aspects & & $0.33^{* *}$ & $0.49 * *$ & $0.60^{* *}$ & $0.39 * *$ & $0.47^{* *}$ & $0.39 * *$ \\
\hline Academic aspects & & & $0.49^{* *}$ & $0.35^{* *}$ & $0.24^{*}$ & $0.33^{* *}$ & 0.19 \\
\hline Reputation & & & & $0.41^{* *}$ & $0.62^{* *}$ & $0.50^{* *}$ & $0.31^{* *}$ \\
\hline Access & & & & & $0.39 * *$ & $0.28^{*}$ & $0.26^{*}$ \\
\hline Program issues & & & & & & $0.29 *$ & $0.36^{* *}$ \\
\hline Word-of-mouth & & & & & & & $0.50^{* *}$ \\
\hline $\begin{array}{l}\text { Intention for further } \\
\text { study }\end{array}$ & & & & & & & \\
\hline
\end{tabular}

\section{Conclusions}

This study contributes to the literature by providing a different picture of the linkage and model between service quality perception, country-of-origin and its implication on the potential behavioral responses among the higher education students. In a nutshell, overall results from this study have shown findings that contradict the past literature. $\mathrm{COO}$ is insignificant when influencing perception of service quality, so is behavioral intention. Unlike general expectation, while academic aspects are often an important aspect of education service quality, in this study, academic aspects failed to link directly to the intention of students to further their study with their existing institution. From a practical perspective, as international students perception of service quality and behavioral intention (word-of-mouth and intention for further study) is not directly influenced by the COO of the institution, it is important for both local and foreign institutions to note that they are now competing for international student enrolment mainly on other aspects of service quality (non-academic aspects, reputation, access and program issues).

This study also raises several concerns which provide avenues for future research. Firstly, it is important to note that this study is based on an analysis of a pilot test sample of less than 80 international students from two institutions (one local, one foreign). Generalizing the results to local students in either institution should be done cautiously. Hence, it is recommended that a similar study should be repeated for local students in both local and foreign institutions to verify the accuracy of the result. In addition to that, a comparative study between both local and international students particularly on COO, perception of service quality and intention for further study will give a better comparative analysis for both local and foreign institutions. Finally, the analysis in this study is based on a simple bivariate analysis. Further analysis with bigger samples using other statistical techniques, such as multiple regressions and structured equation modeling will result in a more rigorous model for the study.

\section{References}

Abdullah, F. (2006). "Measuring Service Quality in Higher Education: HEdPERF Versus SERVPERF," Marketing Intelligence \& Planning, 24(1), 31-47.

Ahmad Faiz, A. L. (2007). Cross-Border Education Elements and Its Relation to the Malaysian Higher Education Scenes, National Higher Education Research Institute, Penang.

Al-Sulaiti, K. I. \& Baker, M. J. (1998). “Country of Origin Effects: A Literature Review," Marketing Intelligence \& Planning, 16(3), 150-199. 
Allen, J. \& Davis, D. (1991). "Searching for Excellence in Marketing Education: The Relationship between Service Quality and Three Outcome Variables," Journal of Marketing Education, 13(1), 47-55.

Athanassopoulos, A., Gounaris, S. \& Stathakopoulos, V. (2001). "Behavioural Responses to Customer Satisfaction: An Empirical Study," European Journal of Marketing, 35(5/6), 687-707.

Athiyaman, A. (1997). "Linking Student Satisfaction and Service Quality Perceptions: The Case of University Education," European Journal of Marketing, 31(7), 528-540.

Athiyaman, A. (2000). "Perceived Service Quality in the Higher Education Sector: An Empirical Analysis," Proceedings of Australian \& New Zealand Marketing Academy Conference (ANZMAC 2000), 28 November - 1 December, Gold Coast, Australia, 50-55.

Bai, B., Law, R. \& Wen, I. (2008). "The Impact of Website Quality on Customer Satisfaction and Purchase Intentions: Evidence from Chinese Online Visitors," International Journal of Hospitality Management, 27(3), 391-402.

Berentzena, J. B., Backhausa, C., Michaelisa, M., Blutb, M. \& Ahlerta, D. (2008). "Does "Made in ..." Also Apply to Services? An Empirical Assessment of the Country-ofOrigin Effect in Service Settings," Journal of Relationship Marketing, 7(4), 391-405.

Bernardi, R. A. (1994). "Validating Research Results When Cronbach "S Alpha Is Below .70: A Methodological Procedure," Educational and Psychological Measurement, 54(3), 766-775.

Bilkey, W. J. \& Nes, E. (1982). "Country of Origin Effects on Product Evaluation," Journal of International Business Studies, 8(1), 89-99.
Boulding, W., Kaira, A., Stelin, R. \& Zeithaml, V. A. (1993). "A Dynamic Process Model of Service Quality: From Expectations to Behavioral Intentions," Journal of Marketing Research, 30(February), 7-27.

Bove, L., Robertson, N. \& Pervan, S. (2003). "Customer Citizenship Behaviours: Towards the Development of a Typology," Proceedings of the 2003 Australian and New Zealand Marketing Academy Conference (ANZMAC), 1-3 December 2003, Adelaide, Australia, 331-338.

Brocado. (2009). “Comparing Alternative Instruments to Measure Service Quality in Higher Education," Quality Assurance in Education, 17(2), 174-190.

Chattalas, M., Kramer, T. \& Takada, H. (2008). "The Impact of National Stereotypes on the Country of Origin Effect: A Conceptual Framework," International Marketing Review, 25(1), 54-74.

Chryssochoidis, G., Krystallis, A. \& Perreas, P. (2007). "Ethnocentric Beliefs and Countryof-Origin (COO) Effect Impact of Country, Product and Product Attributes on Greek Consumers' Evaluation of Food Products," European Journal of Marketing, 41(11/12), 1518-1544.

Cronin, J. J. \& Taylor, S. A. (1992). "Measuring Service Quality: A Re-Examination and Extension," Journal of Marketing, 56(3), 5568.

Cronin, J. J. \& Taylor, S. A. (1994). "SERVPERF Versus SERVQUAL: Reconciling Performance-Based and Perceptions-MinusExpectations Measurement of Service Quality," Journal of Marketing, 58(1), 125-31.

Crosby, P. B. (1979). Quality Is Free: the Art of Making Quality Certain, Mcgraw-Hill, New York. 
Drucker, P. F. (1985). Innovation and Entrepreneurship, Harper \& Row, New York.

Fen, Y. S. \& Lian, K. M. (2007). "Service Quality and Customer Satisfaction: Antecedents of Customer's Re-Patronage Intentions," Sunway Academic Journal, 4, 5973.

George, D. \& Mallery, P. (2003). 'Using SPSS for Windows Step By Step: A Simple Guide and Reference,' 11.0 Update (4th Ed.), Allyn \& Bacon, Boston.

Javalgi, R. G., Cutler, B. D. \& Winans, W. A. (2001). "At Your Service! Does Country of Origin Research Apply to Services?," Journal of Services Marketing, 15(7), 565-582.

Joseph, M. \& Joseph, B. (1997). "Service Quality in Education: A Student Perspective," Quality Assurance in Education, 5(1), 15-21.

Joseph, M. \& Joseph, B. (2000). "Indonesian Students' Perceptions of Choice Criteria in the Selection of a Tertiary Institution: Strategic Implications," International Journal of Educational Management, 14(1), 40-44.

Joseph, M., Yakhou, M. \& Stone, G. (2005). "An Educational Institution's Quest for Service Quality: Customers' Perspective," Quality Assurance in Education, 13(1), 66-82.

Juran, J. M. (1945). 'Management of Inspection and Quality Control,' Harper \& Bros, New York.

LeBlanc, G. \& Nguyen, N. (1997). "Searching for Excellence in Business Education: An Exploratory Study for Customer Impressions of Service Quality," International Journal of Educational Management, 11(2), 72-79.

Li, J. \& Liu, F. (2009). “Country Image and Service Quality of Higher Education Industry - Chinese Students' Enrollment in an Offshore Program," Proceedings of the 6th International Conference on Service Systems and Service Management 2009 (ICSSM'09), ISBN: 978-1-4244-3661-3, 8-10 June 2009, Xiamen, China, 375-380.

Mazzarol, T. \& Soutar, G. N. (2002). "PushPull" Factors Influencing International Student Destination Choice," The International Journal of Educational Management, 16(2), 82-90.

Meng, S.- M., Liang, G.- S. \& Yang, S.- H. (2011). "The Relationship of Cruise Image, Perceived Value, Satisfaction, and PostPurchase Behavioral Intention on Taiwanese Tourist," African Journal of Business Management, 5(1), 19-29.

MOHE. (2010). "Ministry of Higher Education," International Students, [Online], [Retrieved February 20, 2011], http://www.portal.mohe.gov.my/portal/pag e/portal/ExtPortal/STUDENT/INTERNATIO NAL_STUDENT/Student_International_Bilan gan

Nguyen, N. \& LeBlanc, G. (2001). "Image and Reputation of Higher Education Institutions in Students' Retention Decisions," The International Journal of Management, 15(6), 303-311.

Oldfield, B. M. \& Baron, S. (2000). "Student Perceptions of Service Quality in a UK University Business and Management Faculty," Quality Assurance in Education, 8(2), 85-95.

O'Neill, M. A. \& Palmer, A. (2004). "Importance-Performance Analysis: A Useful Tool for Directing Continuous Improvement in Higher Education," Quality Assurance in Education, 12(1), 39-52.

Palmer, A. (2008). 'Principles of Services Marketing,' Mcgraw-Hill, Berkshire, UK. Pecotich, A., Pressley, M. \& Roth, D. (1996). "The Impact of Country of Origin in the Retail Service Context," Journal of Retailing and Consumer Services, 3(4), 213-224. 
Pérez, M. S., Abad, J. C., Carrillo, G. M. \& Fernández, R. S. (2007). "Effects of Service Quality Dimensions on Behavioural Purchase Intentions: A Study in Public-Sector Transport," Managing Service Quality, 17(2), 134-151.

Stanton, M. \& Veale, R. (2009). "Decomposing County of Origin Dimensions for Services: An Investigation into Perceptions of Service Quality in a Transnational Setting," Proceedings of the Australian \& New Zealand Marketing Academy Conference (ANZMAC 2009), 30 November - 2 December 2009, Melbourne, Australia, 1-9.

Verlegh, P. W. J. \& Steenkamp, J.- B. E. M. (1999). "A Review and Meta-Analysis of Country-of-Origin Research," Journal of Economic Psychology, 20, 521-546.

Voss, R., Gruber, T. \& Szmigin, I. (2007). "Service Quality in Higher Education: The Role of Student Expectations," Journal of Business Research, 60, 949-959.

Webb, D. \& Po, K. (2000). "Country-of-Origin and Brand Effects in a University Setting," Proceedings of the Australian \& New Zealand Marketing Academy Conference (ANZMAC 2000), 28 November - 1 December 2000, Gold Cost, Queensland, 1376-1380.

Yan, Y. L, Ho, J. S. Y. \& Ng, L. Y. (2008). 'Service Quality of a Private Higher Education Institute: What Have International Students Got to Say?,' Proceedings of the TARC International Conference (TIC 2008), 4-5 August 2008, Kuala Lumpur, 1-8.

Yeo, R. K. (2009). "Service Quality Ideals in a Competitive Tertiary Environment," International Journal of Educational Research, 48, 62-76.

Zeithaml, V. A., Berry, L. L. \& Parasuraman, A. (1996). "The Behavioural Consequences of Service Quality," Journal of Marketing, 60(April), 31-46.
Zeithaml, V. A. \& Bitner, M. J. (2003). 'Service Marketing: Integrating Customer Focus Across the Firm,' Mcgraw-Hill, New York.

Zeithaml, V. A., Parasuraman, A. \& Berry, L. L. (1990). 'Delivering Quality Service, Balancing Customer Perceptions and Expectations,' The Free Press, New York.

Zhang, Y. (1996). “Chinese Consumers' Evaluation of Foreign Products: The Influence of Culture, Product Types, and Product Presentation Format," European Journal of Marketing, 30(12), 50-69. 